\title{
Application of Protocols Devised to Study Bi(III) Complex Formation by Voltammetry: The Bi(III)-Picolinic Acid System
}

\author{
Caren Billing $^{* \dagger}$ and Ignacy Cukrowski ${ }^{\ddagger}$ \\ ' Molecular Sciences Institute, School of Chemistry, University of the Witwatersrand, P.O. Wits, Johannesburg, \\ 2050, South Africa \\ ${ }^{\ddagger}$ Department of Chemistry, University of Pretoria, Pretoria, 0002, South Africa
}

*E-mail: caren.billing@wits.ac.za. Phone: +27 11 717-6768.

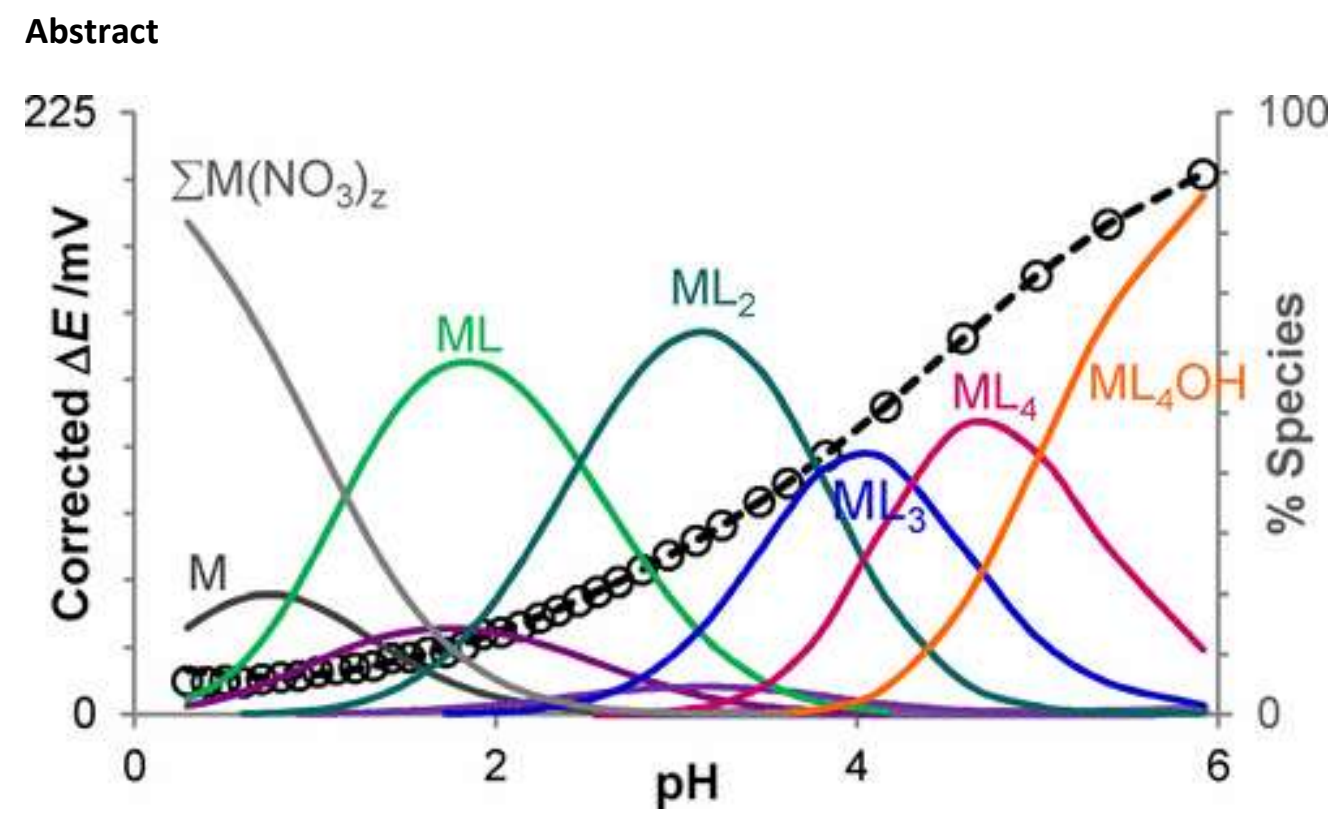

$\mathrm{Bi}(\mathrm{III})$ coordination chemistry has been largely neglected due to the difficulties faced when studying these systems even though $\mathrm{Bi}(\mathrm{III})$ is used in various medicinal applications. This study of the $\mathrm{Bi}(\mathrm{III})-$ picolinic acid system by voltammetry applies the rigorous methodologies already developed to enable the study of $\mathrm{Bi}(\mathrm{III})$ systems starting in very acidic solutions to prevent precipitation. This includes calibrating the glass electrode accurately at these low $\mathrm{pHs}$, compensating for the diffusion junction potential below $\mathrm{pH} 2$ and determining the reduction potential of uncomplexed $\mathrm{Bi}$ (III) which cannot be directly measured. The importance of including nitrate from the background electrolyte as a competing species is highlighted, especially for data acquired below $\mathrm{pH} \sim 2$. From analysis of the voltammetric data, it was not clear whether a $\mathrm{ML}_{3} \mathrm{OH}$ species formed in solution or whether it was a combination of $\mathrm{ML}_{4}$ and $\mathrm{ML}_{4} \mathrm{OH}$. Information from crystal structures and electrospray ionizationmass spectrometry measurements was thus used to propose the most probable species model. The $\log \beta$ values determined were $7.77 \pm 0.07$ for $\mathrm{ML}, 13.89 \pm 0.07$ for $\mathrm{ML}_{2}, 18.61 \pm 0.01$ for $\mathrm{ML}_{3}, 22.7 \pm$ 0.2 for $\mathrm{ML}_{4}$, and $31.4 \pm 0.2$ for $\mathrm{ML}_{4} \mathrm{OH}$. Application of these methodologies thus opens the door to broaden our understanding of $\mathrm{Bi}(\mathrm{III})$ complexation. 


\section{Introduction}

Bismuth has been used in medicinal preparations for decades, as highlighted in several review articles.(1-7) The most widespread use of bismuth compounds is in the treatment of peptic ulcers where bismuth acts against Helicobacter pylori found in the human gastric mucosa which is responsible for these ulcers. $(3,8-11)$ The antibacterial characteristics of bismuth have led to its use in treating other bacterial or yeast infections. $(1,3,12-14)$ The use of bismuth compounds as antitumor drugs has also been investigated. $(1,5,15,16)$ The ${ }^{212} \mathrm{Bi}$ and ${ }^{213} \mathrm{Bi} \alpha$-particle emitters show potential therapeutic value due to their short half-lives (61 and $46 \mathrm{~min}$, respectively) and low penetration $(50-90 \mu \mathrm{m})$ which reduces toxicity to the surrounding healthy tissue. $(1,3-5)$

Despite the variety of current and possible future medicinal uses of $\mathrm{Bi}(\mathrm{III})$, the coordination chemistry and biochemistry of bismuth are still poorly understood. $(1,3)$ The deficiency of stability constant data for $\mathrm{Bi}(\mathrm{III})$ complexes is due to numerous difficulties experienced in these studies. The strong tendency of $\mathrm{Bi}(\mathrm{III})$ to hydrolyze in aqueous solutions causes hydrolysis products to form below $\mathrm{pH}$ 1.(17) Furthermore, anions from the background electrolyte form insoluble salts with the

$\mathrm{Bi}_{6}(\mathrm{OH})_{12}{ }^{6+}$ polycondensate which precipitates under acid conditions (around $\mathrm{pH} 2$ ). (18) In this work, current sampled DC polarography was used to study $\mathrm{Bi}(\mathrm{III})$ complexation, since relatively low $\mathrm{Bi}$ (III) concentrations $\left(\sim 10^{-5} \mathrm{M}\right)$ can be used, thereby postponing precipitation to higher $\mathrm{pHs}$ and reducing the extent of formation of polynuclear species. Complexation by certain ligands increases the solubility of $\mathrm{Bi}(\mathrm{III})$, but this must occur at low $\mathrm{pH}$ while $\mathrm{Bi}(\mathrm{III})$ is in solution. Large ligand-to-metal ion concentration ratios drive complex formation, thus making voltammetry an ideal technique for these studies, as this is a requirement to ensure that the solution at the electrode surface during measurement represents the bulk conditions (generally [L]:[M] > 50).

That being said, several obstacles had to be overcome before this technique could be employed to produce accurate formation constants. First, the procedure used to calibrate the glass electrode (GE) had to be reassessed. Usually, when calibrating the GE using a strong acid-strong base titration, it is recommended that narrow $\mathrm{pH}$ ranges (such as $\mathrm{pH} 2.3-2.9$ and 10.8-11.3(19-21)) be used to obtain a linear response. This is impossible to apply when studies must commence well below $\mathrm{pH} 2$, as in the case for $\mathrm{Bi}(\mathrm{III})$. Thus, procedures to accurately calibrate the GE below $\mathrm{pH} 2$ were developed which involved taking the slight deviation from linearity in the very acidic region into account so that the function describing the potential-pH profile represented the experimental values as closely as possible.(22) Second, in the voltammetric cell used, the diffusion junction potential $\left(E_{\mathrm{j}}\right)$ was significant below pH 2 and increased considerably with decreasing $\mathrm{pH}$. Protocols were developed using $\mathrm{TI}(\mathrm{I})$ as an in situ reference ion to evaluate and hence account for $E_{\mathrm{j}}$ in the cell used in metalligand equilibria studies at each step in the $\mathrm{pH}$ titration. $(23,24)$ Third, the reduction potential of uncomplexed $\mathrm{Bi}(I I I)(E(B i))$ is required to calculate formation constants. This value cannot be determined directly, as $\mathrm{Bi}(\mathrm{III})$ hydroxide species already exist below $\mathrm{pH} 2$. Additionally, the nitrate background electrolyte employed which ensured that the $\mathrm{Bi}(\mathrm{III})$ reduction waves were reversible resulted in $\mathrm{Bi}(\mathrm{III})$ nitrate complexes forming below $\mathrm{pH} 3$. The methodology whereby $E(\mathrm{Bi})$ was determined by correcting for shifts in potential due to the formation of these species was also developed.(25) 
This paper presents the investigation of the Bi(III)-picolinic acid system. Picolinic acid is endogenously produced as an intermediate during the degradation of L-tryptophan, an essential amino acid, and has been shown to have a wide range of immunological, neuro-protective, and antiproliferative effects in the human body.(26) Since early studies showed that the oral administration of picolinic acid promoted the absorption of several metals via the small intestine, $(27,28)$ studies with numerous metal ions such as $\mathrm{Cu}(\mathrm{II}), \mathrm{Cr}(\mathrm{III}), \mathrm{Zn}(\mathrm{II})$, and $\mathrm{VO}(\mathrm{II})$ have followed. For example, the complexation of zinc by picolinic acid was shown to increase the bioavailability of zinc in humans and is present in breast milk.(29)

Table 1. Constants for the Given Equilibria at $25^{\circ} \mathrm{C}$ and the Given lonic Strengths $(\mu)(33)$

\begin{tabular}{|c|c|c|}
\hline equilibrium & $\log \beta$ & $\mu(\mathrm{M})$ \\
\hline $\mathrm{H}_{2} \mathrm{O} \rightleftharpoons \mathrm{H}^{+}+\mathrm{OH}^{-}$ & -13.74 & 0.5 \\
\hline $\mathrm{L}^{-}+\mathrm{H}^{+} \rightleftharpoons \mathrm{HL}$ & 5.18 & 0.5 \\
\hline $\mathrm{HL}+\mathrm{H}^{+} \rightleftharpoons \mathrm{H}_{2} \mathrm{~L}^{+}$ & $(0.86)$ & 0.5 \\
\hline $\mathrm{Bi}^{3+}+\mathrm{OH}^{-} \rightleftharpoons \mathrm{Bi}(\mathrm{OH})^{2+}$ & $12.42^{\mathrm{a}}$ & 0.5 \\
\hline $\mathrm{Bi}^{3+}+2 \mathrm{OH}^{-} \rightleftharpoons \mathrm{Bi}(\mathrm{OH})_{2}^{+}$ & 23.5 & 1.0 \\
\hline $\mathrm{Bi}^{3+}+3 \mathrm{OH}^{-} \rightleftharpoons \mathrm{Bi}(\mathrm{OH})_{3}$ & $31.88^{\mathrm{a}}$ & 0.5 \\
\hline $\mathrm{Bi}^{3+}+4 \mathrm{OH}^{-} \rightleftharpoons \mathrm{Bi}(\mathrm{OH})_{4}^{-}$ & $32.98^{\mathrm{a}}$ & 0.5 \\
\hline $6 \mathrm{Bi}^{3+}+12 \mathrm{OH}^{-} \rightleftharpoons \mathrm{Bi}_{6}(\mathrm{OH})_{12}^{6+}$ & $162.78^{\mathrm{a}}$ & 0.5 \\
\hline $9 \mathrm{Bi}^{3+}+20 \mathrm{OH}^{-} \rightleftharpoons \mathrm{Bi}_{9}(\mathrm{OH})_{20}{ }^{7+}$ & $266.92^{\mathrm{a}}$ & 0.5 \\
\hline $9 \mathrm{Bi}^{3+}+21 \mathrm{OH}^{-} \rightleftharpoons \mathrm{Bi}_{9}(\mathrm{OH})_{21}^{6+}$ & $276.76^{\mathrm{a}}$ & 0.5 \\
\hline $9 \mathrm{Bi}^{3+}+22 \mathrm{OH}^{-} \rightleftharpoons \mathrm{Bi}_{9}(\mathrm{OH})_{22}^{5+}$ & $287.30^{\mathrm{a}}$ & 0.5 \\
\hline $\mathrm{Bi}^{3+}+\mathrm{NO}_{3}^{-} \rightleftharpoons \mathrm{Bi}\left(\mathrm{NO}_{3}\right)^{2+}$ & 0.72 & 0.5 \\
\hline $\mathrm{Bi}^{3+}+2 \mathrm{NO}_{3}^{-} \rightleftharpoons \mathrm{Bi}\left(\mathrm{NO}_{3}\right)_{2}^{+}$ & $(0.94)$ & 0.5 \\
\hline $\mathrm{Bi}^{3+}+3 \mathrm{NO}_{3}^{-} \rightleftharpoons \mathrm{Bi}\left(\mathrm{NO}_{3}\right)_{3}$ & 0.7 & 1.0 \\
\hline $\mathrm{Bi}^{3+}+4 \mathrm{NO}_{3}^{-} \rightleftharpoons \mathrm{Bi}\left(\mathrm{NO}_{3}\right)_{4}^{-}$ & 0.6 & 2.0 \\
\hline
\end{tabular}

Aside from its biochemical relevance, picolinic acid has been shown to form complexes under very acidic conditions (due to the low $\mathrm{p} K_{\mathrm{a} 1}$ value as shown in Table 1 ) and complexation with Bi(III) has been studied by voltammetry once before.(30) Their work, however, uses less rigorous methodologies and the role of the $\mathrm{Bi}(\mathrm{III})$ nitrates was not yet realized.(30) The work presented here is the culmination of various studies done up to this point,(22-25) as it illustrates how the protocols that were designed to ultimately study Bi(III)-ligand systems are applied. 


\section{Experimental Section}

\subsection{Materials}

Analytical grade reagents and deionized water (resistivity $=18 \mathrm{M} \Omega \mathrm{cm}$ ) were always used. Stock solutions of $0.100 \mathrm{M} \mathrm{TI}(\mathrm{I})$ nitrate in $0.5 \mathrm{M} \mathrm{HNO}_{3}$ and $0.100 \mathrm{M} \mathrm{Bi}(\mathrm{III})$ nitrate in $1 \mathrm{M} \mathrm{HNO}_{3}$ were made as before.(25) Picolinic acid (PA) was supplied by Aldrich (99\%, Milwaukee, USA).

\subsection{Instrumentation}

Polarographic experiments were carried out in a jacketed cell maintained at $25.0 \pm 0.1^{\circ} \mathrm{C}$ which contained electrodes supplied by Metrohm (Herisau, Switzerland) as follows: a dropping mercury working electrode, a $\mathrm{Ag} / \mathrm{AgCl}(3 \mathrm{M} \mathrm{KCl})$ reference electrode in a $0.5 \mathrm{M} \mathrm{KNO}_{3}$ salt bridge, a platinum counter electrode, and a combination glass electrode ( $3 \mathrm{M} \mathrm{KCl}$, Metrohm cat. no. 6.0234.100), as well as a thermocouple to monitor the solution temperature. A BAS CV27 potentiostat was used as part of an automated setup as described in detail elsewhere.(31) Current sampled DC polarography was employed with a step time of $1 \mathrm{~s}$, a current integration time of $100 \mathrm{~ms}$, and a step potential of 4 $\mathrm{mV}$.

Electrospray ionization-mass spectrometry (ESI-MS) was performed using a Thermo LXQ with a linear ion trap. The capillary temperature and voltage were $200^{\circ} \mathrm{C}$ and $24 \mathrm{~V}$, respectively, the ESI voltage was $3 \mathrm{kV}$, and the sheath gas flow rate was 10 (arbitrary units). Samples were continuously introduced into the ionization source using a syringe pump while data was collected. Sample solutions were purely aqueous and contained $1 \times 10^{-4} \mathrm{M} \mathrm{Bi}(\mathrm{III}), 1 \times 10^{-2} \mathrm{M} \mathrm{PA}$, and $0.5 \mathrm{M} \mathrm{NO}_{3}{ }^{-}$to reflect conditions used when determining formation constants as closely as possible. Solutions were adjusted to $\mathrm{pH} 4.0$ and 6.9 using $\mathrm{KOH}$.

\subsection{Procedure}

The GE was calibrated before and after each experiment by the titration of $0.5 \mathrm{M} \mathrm{HNO}_{3}$ by $0.5 \mathrm{M}$ $\mathrm{KOH}$ (both standardized) as described before;(22) thus, $\mathrm{pH}$ implies $-\log \left[\mathrm{H}^{+}\right]$in this work. Three polarographic-pH titration experiments were performed, each having initial solutions of $0.5 \mathrm{M} \mathrm{HNO}_{3}$ with $1.0 \times 10^{-5} \mathrm{M} \mathrm{Bi}(I I I)$ and $2.0 \times 10^{-5} \mathrm{M} \mathrm{TI}(\mathrm{I})$. A polarogram and the GE potential were recorded in this solution before adding a known mass of PA such that the total ligand-to- $\mathrm{Bi}(I I I)$ concentration ratios ([PA $]$ : $\left[\mathrm{Bi}_{\mathrm{T}}\right]$ ) were 94,148 , or 197 . These solutions were then titrated with $0.5 \mathrm{M} \mathrm{KOH}$, with a polarogram and the GE potential being recorded after each $\mathrm{pH}$ step of about 0.1 (see Figure $\mathrm{S} 1$ in the Supporting Information for a selected set of polarograms). An attempt was made to work at a reasonable ionic strength $(\mu)$ of $\sim 0.5 \mathrm{M}$ while employing very acidic initial conditions; thus, $\mu$ did vary between 0.5 and $0.25 \mathrm{M}$ during the titration because the acid and base solutions did not contain supporting electrolyte.

The $\mathrm{DC}$ reduction waves for $\mathrm{Bi}(\mathrm{III})$ and $\mathrm{TI}(\mathrm{I})$ were fitted separately, as before, $(25)$ to determine the half-wave potentials $\left(E_{1 / 2}\right)$ and diffusion-limited currents $\left(I_{\mathrm{d}}\right)$ at each $\mathrm{pH}$ step. The reduction waves showed reversible behavior in the presence of picolinic acid (as was previously found in the absence of ligand in a $0.5 \mathrm{M}$ nitrate solution(25)). The values of $E_{\mathrm{j}}$ (below $\mathrm{pH} \sim 2$ ) were calculated as a 
function of $\mathrm{pH}$ using the $E_{1 / 2}(\mathrm{TI})$ values as previously described, $(23,24)$ and hence, the $E_{1 / 2}(\mathrm{Bi})$ values were corrected for shifts due to changes in $E_{\mathrm{j}}$.

Formation constants were calculated using the relationship proposed by Cukrowski(32)

$\left\{E(\mathrm{M})-E\left(\mathrm{M}_{\text {comp }}\right)_{\mathrm{pH}}\right\}-\frac{R T}{n F} \ln \frac{I\left(\mathrm{M}_{\text {comp }}\right)_{\mathrm{pH}}}{I(\mathrm{M})_{\mathrm{pH}}}=\frac{R T}{n F} \ln \frac{\left[\mathrm{M}_{\mathrm{T}}\right]_{\mathrm{pH}}}{[\mathrm{M}]_{\mathrm{pH}}}(1)$

where $E(M)$ and $E\left(\mathrm{M}_{\text {comp }}\right)$ are the half-wave potentials of the free (uncomplexed) and complexed metal ion, $I(\mathrm{M})$ and $I\left(\mathrm{M}_{\text {comp }}\right)$ are the diffusion-limited currents for the free and complexed metal ion, and $[\mathrm{M}]$ and $\left[\mathrm{M}_{\mathrm{T}}\right]$ are the free and total metal ion concentrations, respectively. The subscript $\mathrm{pH}$ indicates the parameters that are functions of $\mathrm{pH}$ (for $/(\mathrm{M})$ and $\left[\mathrm{M}_{\mathrm{T}}\right]$, this only applies to account for dilution when adjusting $\mathrm{pH}$ ). These parameters are all determined experimentally, except for [M] which is found by solving mass-balance equations (MBEs) which include the formation constants for each solution species. Protonation constants for $\mathrm{PA}, \mathrm{Bi}(\mathrm{III})$-hydroxide, and $\mathrm{Bi}(\mathrm{III})$-nitrate formation constants and the dissociation constant for water used in the refinement process when determining formation constants for the $\mathrm{Bi}(\mathrm{III})-\mathrm{PA}$ species are given in Table 1 . The left side of eq 1 , which calculates the corrected potential shifts, gives the experimental complex formation curve (ECFC) when plotted vs $\mathrm{pH}$, and the right side of the equation plotted vs $\mathrm{pH}$ gives the calculated complex formation curve (CCFC). The metal-ligand species model and the respective formation constants are refined such that the CCFC fits the ECFC as closely as possible.

\section{Results and Discussion}

\subsection{Determining Stability Constants from Voltammetric Data Using Dedicated Software}

When studying the complexation of $\mathrm{Bi}(\mathrm{III})$ by various ligands using polarography, the presence of $\mathrm{Tl}(\mathrm{I})$ as an internal reference is essential. It is used in each experiment to monitor $E_{\mathrm{j}}$ as well as to predict the value of $E(\mathrm{Bi})$. From similar experiments run without added ligand,(25) it was illustrated that, once the measured $E_{1 / 2}(\mathrm{Bi})$ values were corrected for shifts in potential due to $E_{\mathrm{j}}$ and the formation of $\mathrm{Bi}(\mathrm{III})$-hydroxide and $\mathrm{Bi}(\mathrm{III})$-nitrate species, $E(\mathrm{Bi})$ was determined by averaging these corrected $E_{1 / 2}$ values. The difference in the free metal ion potentials for $\mathrm{Bi}(\mathrm{III})$ and $\mathrm{TI}(\mathrm{I})$, i.e., $\Delta E(\mathrm{M})=E(\mathrm{Bi})-$ $E(T I)$, was determined for five experiments under the same experimental conditions as used in this work and was found to be $495.3 \pm 1.5 \mathrm{mV}$. Furthermore, a conditional free $\mathrm{Bi}(\mathrm{III})$ potential, $E_{\mathrm{c}}(\mathrm{Bi})$, was determined by correcting only for shifts in potential due to $E_{\mathrm{j}}$ and the formation of $\mathrm{Bi}(\mathrm{III})-$ hydroxides, as would occur in the presence of the $B i(I I I)$-nitrate species.(25) The value of $\Delta E_{c}(\mathrm{M})=$ $E_{\mathrm{c}}(\mathrm{Bi})-E(\mathrm{Tl})$ was found to be $484.5 \pm 1.7 \mathrm{mV}$ for the five experiments and only applies in the $\mathrm{pH}$ range where the $\mathrm{Bi}(\mathrm{III})$-nitrate species are dominant in solution. The difference of $10.8 \mathrm{mV}$ between $\triangle E(\mathrm{M})$ and $\Delta E_{\mathrm{c}}(\mathrm{M})$ is thus due to the formation of $\mathrm{Bi}(\mathrm{III})$-nitrates. It should be noted that both $E(\mathrm{Bi})$ and $E_{\mathrm{c}}(\mathrm{Bi})$ were calculated using data only up to $\mathrm{pH} \sim 2$, after which precipitation of a bismuth-oxynitrate species occurred. In an experiment that contains ligand, $E(\mathrm{Bi})$ or $E_{\mathrm{c}}(\mathrm{Bi})$ can be calculated using these average values for $\Delta E(\mathrm{M})$ or $\Delta E_{c}(\mathrm{M})$, respectively, and the $E(\mathrm{Tl})$ value determined for that particular experiment, since $\mathrm{TI}(\mathrm{I})$ does not readily form complexes. In previous studies, no

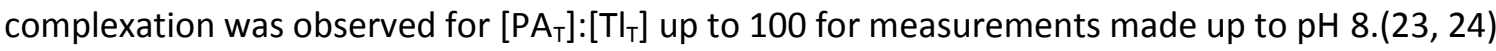


Figure 1 shows the plot of experimental $E_{1 / 2}(\mathrm{Bi})(0)$ vs $\mathrm{pH}$ where $\left[\mathrm{PA}_{\mathrm{T}}\right]:\left[\mathrm{Bi}_{\mathrm{T}}\right]=197$, as well as the $E_{1 / 2}$ values after correction for $E_{\mathrm{j}}(\times)$. Both the $E(\mathrm{Bi})$ and $E_{\mathrm{c}}(\mathrm{Bi})$ values as determined for this experiment are also displayed. It was noted that the difference between $E(B i)$ and the first corrected data point at $\mathrm{pH} 0.3$ (shown in bold, $x$, in Figure 1) was $10.9 \mathrm{mV}$. This difference would be ascribed to complex formation. On closer analysis, a comparison of the $\mathrm{Bi}($ III) reduction waves before and after the addition of PA (at pH 0.3) showed no significant shift (see Figure S2 in the Supporting Information), thereby indicating that the noted difference of $10.9 \mathrm{mV}$ is not due to the formation of $\mathrm{Bi}(\mathrm{III})-\mathrm{PA}$ species but rather $\mathrm{Bi}(\mathrm{III})$-nitrates. This is also supported by the difference between $\triangle E(\mathrm{M})$ and $\Delta E_{\mathrm{c}}(\mathrm{M})$, stated as being due to the formation of $\mathrm{Bi}(\mathrm{III})$-nitrates, being a similar magnitude (10.8 $\left.\mathrm{mV}\right)$. It is thus important to include nitrate as a competing ligand especially in the $\mathrm{pH}$ range where these species are significant. Unfortunately, the 3D-CFC software used to determine stability constants from polarographic data (as applied in previous work $(23,24)$ ) can only accommodate two ligands simultaneously, one of which is always hydroxide and the other is the ligand being investigated.

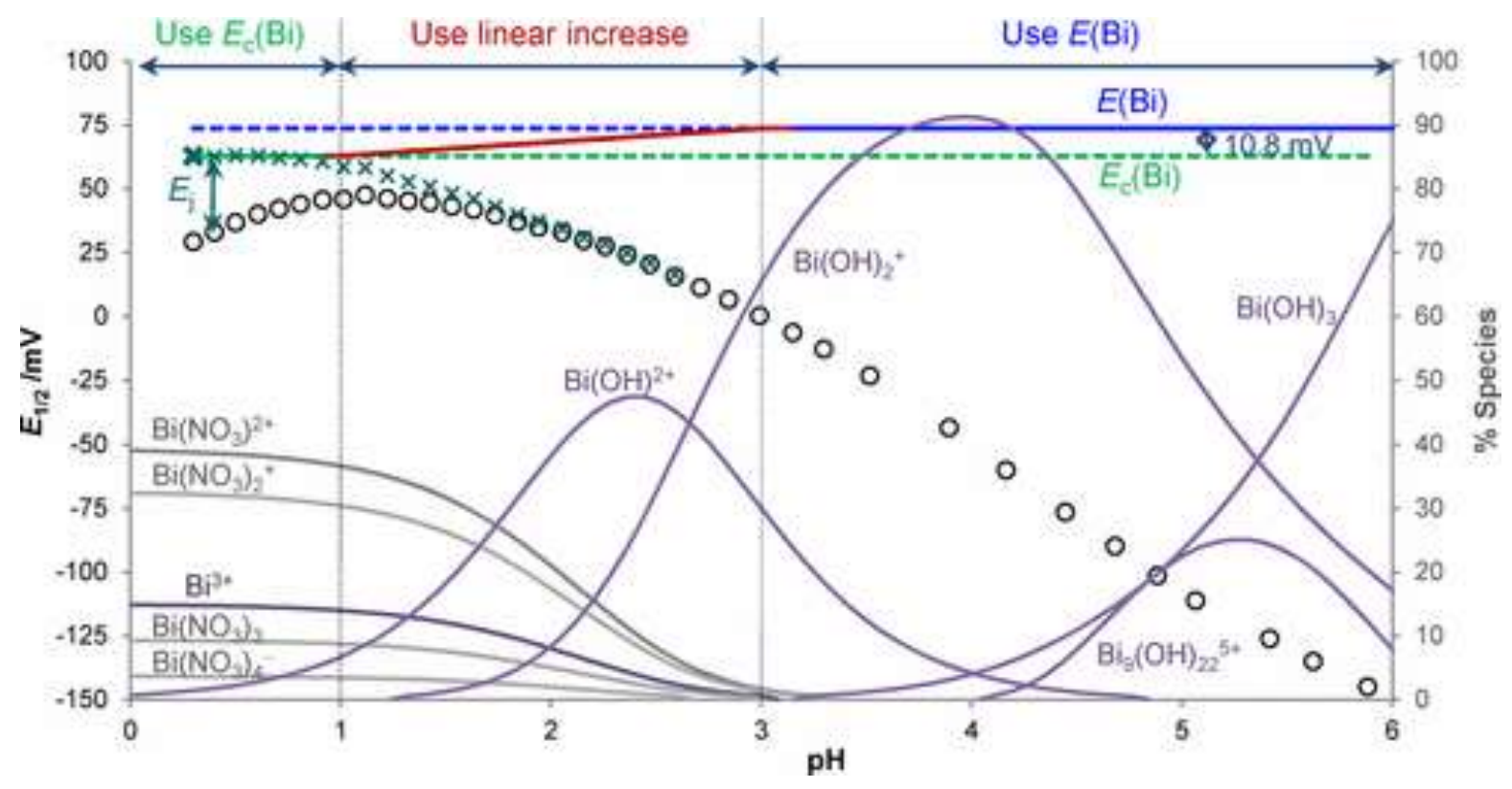

Figure 1. $E_{1 / 2}$ values $(0)$ and those corrected for $E_{\mathrm{j}}(x)$ determined for $\left[\mathrm{PA}_{\mathrm{T}}\right]:\left[\mathrm{Bi}_{\mathrm{T}}\right]=197$ where the initial $[\mathrm{Bi}(\mathrm{III})]=$ $1 \times 10^{-5} \mathrm{M}$ and $\left[\mathrm{NO}_{3}{ }^{-}\right]=0.5 \mathrm{M}$. The $E(\mathrm{Bi})$ and $E_{\mathrm{c}}(\mathrm{Bi})$ values are also shown. The SDD showing the $\mathrm{Bi}(\mathrm{III})$ nitrate and hydroxide species for $[\mathrm{Bi}(\mathrm{III})]=1 \times 10^{-5} \mathrm{M}$ and $\left[\mathrm{NO}_{3}^{-}\right]=0.5 \mathrm{M}$ is given on the secondary axis.

As a guide, the species distribution diagram (SDD) of $1 \times 10^{-5} \mathrm{M} \mathrm{Bi}(\mathrm{III})$ in $0.5 \mathrm{M}$ nitrate (in the absence of $\mathrm{PA}$ ) is shown on the secondary axis in Figure 1 . Below pH 1, where the $\mathrm{Bi}(\mathrm{III})$-nitrate species are dominant in solution, there appears to be negligible complex formation with PA, since changes in the corrected $E_{1 / 2}(\mathrm{Bi})$ values $(x)$ are very small. To accommodate the shortcomings of the software, it was thus proposed that, when calculating the ECFC used to determine the stability constants for the $\mathrm{Bi}(\mathrm{III})-\mathrm{PA}$ system in this $\mathrm{pH}$ region, the potential shift as given in eq 1 should be calculated as $\Delta E=$ $E_{\mathrm{c}}(\mathrm{Bi})-E\left(\mathrm{Bi}_{\text {comp }}\right)$, where $E\left(\mathrm{Bi}_{\text {comp }}\right)$ refers to the values corrected for $E_{\mathrm{j}}(x)$. Above $\mathrm{pH} 3$, where the $\mathrm{Bi}(I I I)-$ nitrates are negligible in solution, it would be more correct to use $\Delta E=E(\mathrm{Bi})-E\left(\mathrm{Bi}_{\text {comp }}\right)$. Between $\mathrm{pH} 1$ and 3 , the free $\mathrm{Bi}(\mathrm{III})$ potential was estimated as the linear increase between $E_{\mathrm{c}}(\mathrm{Bi})$ and $E(\mathrm{Bi})$, since the extent of $\mathrm{Bi}(\mathrm{III})$-nitrates in solution decreased with increasing $\mathrm{pH}$. 
Slope analysis of the ECFCs was done to predict the solution species by considering the red uction reactions occurring, where the slope is approximated as $60 / n \times$ the number of protons involved in the reaction at $25^{\circ} \mathrm{C}$. Slopes of 20,40 , and $60 \mathrm{mV}$ correspond to the reduction of $\mathrm{ML}, \mathrm{ML}_{2}$, and $\mathrm{ML}_{3}$ in the $\mathrm{pH}$ region where $\mathrm{HL}$ is the dominant form of the ligand. Figure $2 \mathrm{a}$ illustrates that all three of these species are thus expected in solution. In the $\mathrm{pH}$ region where the ligand is fully deprotonated, slope analysis can no longer be used provided no $\mathrm{ML}_{x}(\mathrm{OH})_{y}$ species are formed (where the value of $y$ could be determined if there is sufficient data). When including these three species in the model, the CCFC did not describe the ECFC well and it was clear that other species were present at the higher $\mathrm{pH}$ range. In a previous study of the $\mathrm{Bi}(\mathrm{III})-\mathrm{PA}$ system by voltammetry, the species model proposed was $M L, \mathrm{ML}_{2}, \mathrm{ML}_{3}, \mathrm{ML}_{4}$, and $\mathrm{ML}_{3} \mathrm{OH}$.(30) In this case, it was impossible to refine the data when both $\mathrm{ML}_{4}$ and $\mathrm{ML}_{3} \mathrm{OH}$ were included. By adding only $\mathrm{ML}_{3} \mathrm{OH}$, a good fit was achieved (see Figure $2 \mathrm{a}$ ), or alternatively if $\mathrm{ML}_{4}$ was included, the $\mathrm{ML}_{4} \mathrm{OH}$ species also had to be added to obtain a good fit (see Figure $2 \mathrm{~b}$ ). The average $\log \beta$ values (for all three titrations) obtained for both species models as well as those from the literature are given in Table 2. In the Supporting Information, the ECFCs and CCFCs are shown for each experiment (Figure S3) and the individual results are presented in Table S1.
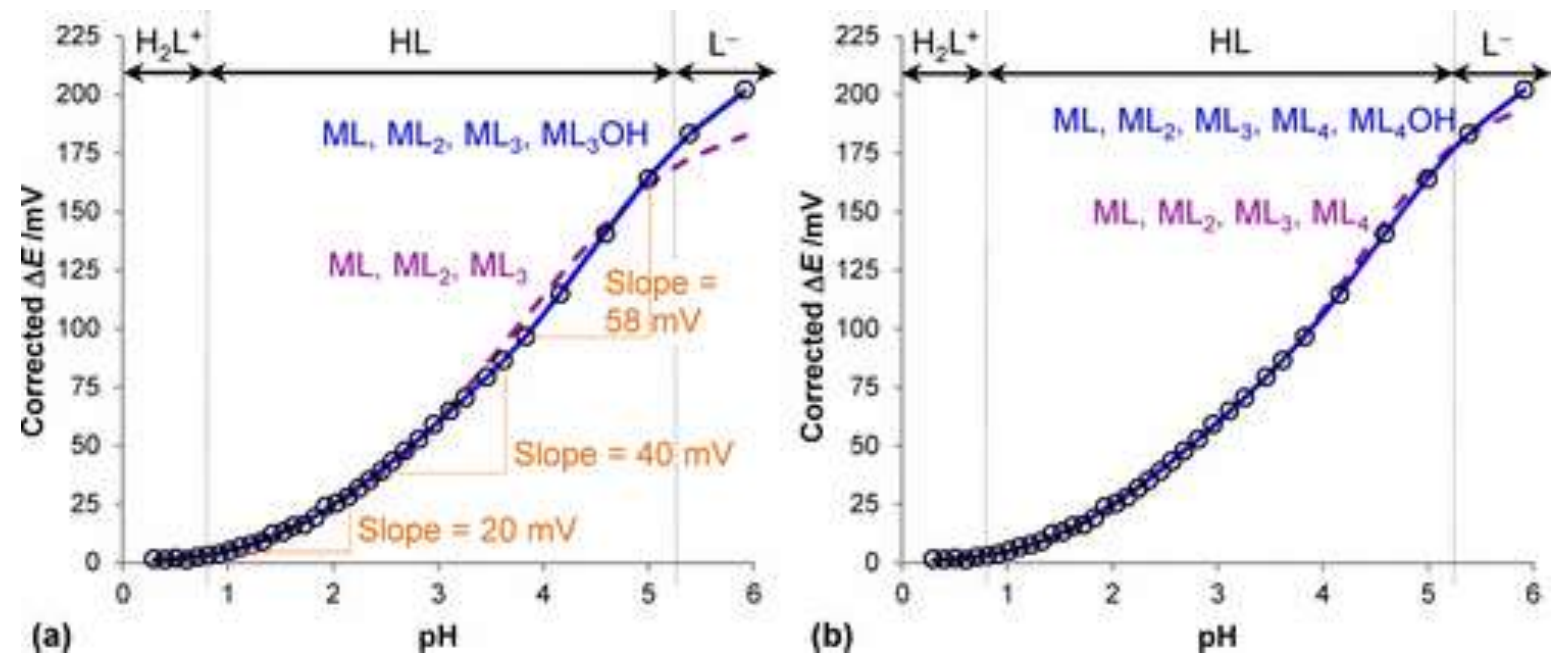

Figure 2. $E C F C$ (points) for $\left[\mathrm{PA}_{\mathrm{T}}\right]:\left[\mathrm{Bi}_{\mathrm{T}}\right]=94$ given with the slope analysis. The species models used to calculate the CCFCs (lines) are indicated. Both the $M L, \mathrm{ML}_{2}, \mathrm{ML}_{3}, \mathrm{ML}_{3} \mathrm{OH}$ model in part a and the $\mathrm{ML}, \mathrm{ML}_{2}, \mathrm{ML}_{3}, \mathrm{ML}_{4}$, $\mathrm{ML}_{4} \mathrm{OH}$ model in part $\mathrm{b}$ give good fits (solid lines). 
Table 2. Average $\log \beta$ Values at $25^{\circ} \mathrm{C}$ for the Two Species Models in This Work at lonic Strength $0.25-0.5 \mathrm{M}$ $(\mathrm{K}, \mathrm{H}) \mathrm{NO}_{3}{ }^{\mathrm{a}}$

$$
\log \beta \text { (this work) } \quad \log \beta \text { (this work) } \quad \log \beta(30)^{b}
$$

$M L$

$6.94 \pm 0.19$

$6.97 \pm 0.16$

$7.48 \pm 0.01$

$\mathrm{ML}_{2}$

$13.93 \pm 0.06$

$13.92 \pm 0.06$

$13.94 \pm 0.01$

$\mathrm{ML}_{3}$

$18.55 \pm 0.06$

$18.64 \pm 0.07$

$18.10 \pm 0.04$

$\mathrm{ML}_{3} \mathrm{OH}$

$28.21 \pm 0.08$

$26.65 \pm 0.03$

$\mathrm{ML}_{4}$

$22.7 \pm 0.2$

$20.47 \pm 0.25$

$\mathrm{ML}_{4} \mathrm{OH}$

$31.5 \pm 0.2$

a These are compared to literature values.

${ }^{b}$ Cukrowski et al.(30) quoted the ionic strength as $0.5 \mathrm{M}(\mathrm{Na}, \mathrm{H}) \mathrm{NO}_{3}$, but their titration procedure would also lead to the ionic strength varying from 0.5 to $0.25 \mathrm{M}$.

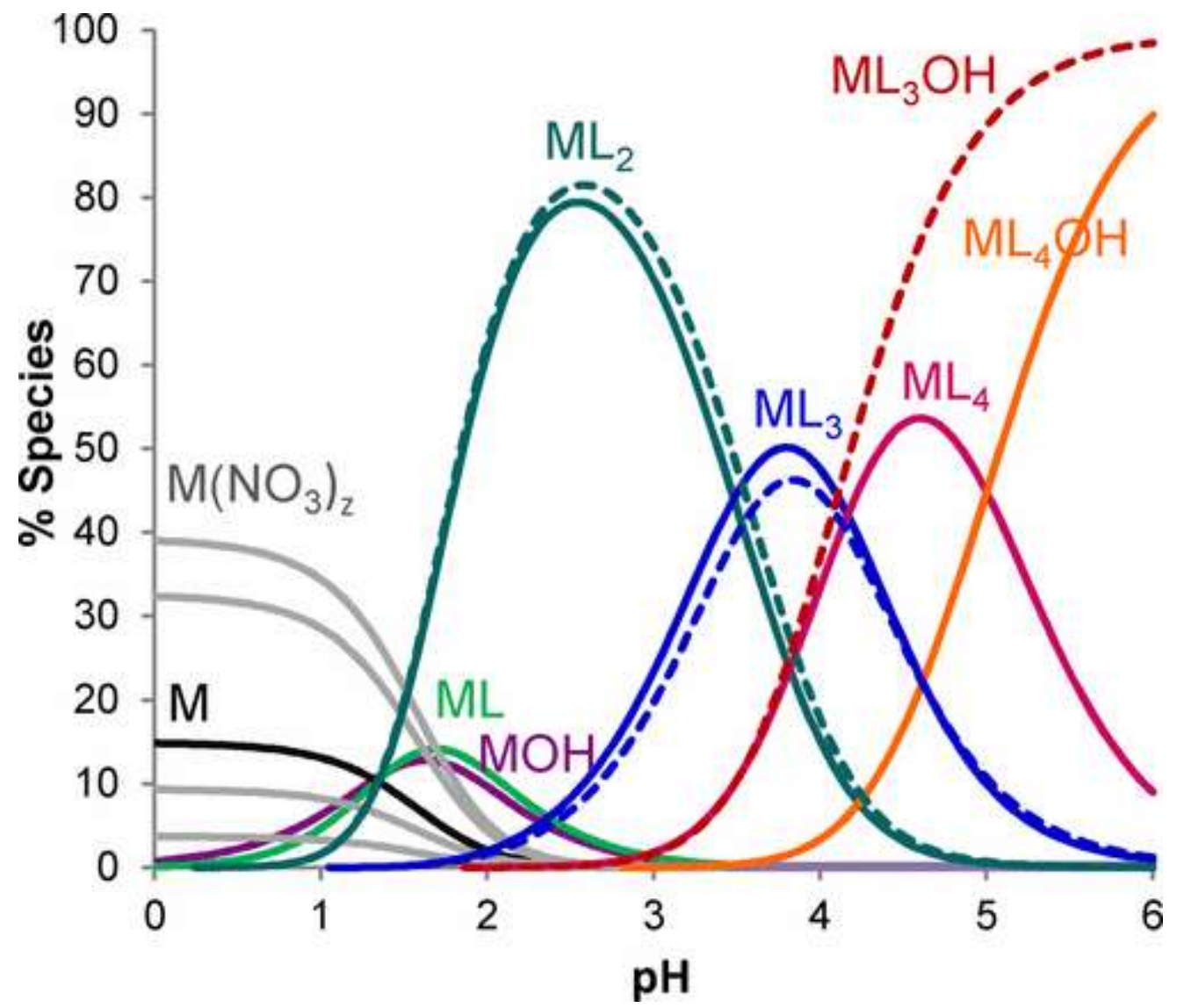

Figure 3. SDDs for $\left[\mathrm{Bi}_{\mathrm{T}}\right]=10^{-5} \mathrm{M},\left[\mathrm{PA}_{\mathrm{T}}\right]=10^{-2} \mathrm{M}$, and $\left[\mathrm{NO}_{3}^{-}{ }_{\mathrm{T}}^{-}\right]=0.5 \mathrm{M}$ using the formation constants determined in this work for the species model including $\mathrm{ML}_{3} \mathrm{OH}$ (dotted lines) or $\mathrm{ML}_{4}$ and $\mathrm{ML}_{4} \mathrm{OH}$ (solid lines). 
From the SDDs plotted using data in Table 2, the two possible species models were compared in Figure 3. It is seen that in the pH range 3-6 the sum of the concentrations for $\mathrm{ML}_{4}$ and $\mathrm{ML}_{4} \mathrm{OH}$ is approximately that for $\mathrm{ML}_{3} \mathrm{OH}$. These species can all conceivably be formed, since $\mathrm{Bi}(\mathrm{III})$ has a highly variable coordination number (ranging between 3 and 10) and frequently has an irregular coordination geometry. $(1,3)$ It is impossible to distinguish which of these species models is correct using only the polarographic data; thus, both crystal structure data and electrospray ionization-mass spectrometry (ESI-MS) measurements were consulted to provide further information.

\subsection{Using ESI-MS and Crystal Structures to Elucidate the Species Model}

The Cambridge Structure Database (CSD)(35) was searched for evidence of structures containing both $\mathrm{PA}$ and $\mathrm{Bi}(\mathrm{III})$, and two were found. These showed $\mathrm{Bi}(\mathrm{III})$ coordinated to three or four PA ligands (REFCODES: YIZVEJ and YIZVAF, respectively). Of particular interest here was the structure for the $\mathrm{ML}_{4}$ arrangement (see Figure S4 in the Supporting Information), where four PA ligands are bonded bidentately to $\mathrm{Bi}(\mathrm{III})$ through pyridyl nitrogen and carboxylate oxygen atoms. Additionally, $\mathrm{Na}^{+}$ions interact with two carboxylate oxygen atoms on adjacent PA ligands that are bonded to $\mathrm{Bi}(\mathrm{III})$ which could stabilize the $\mathrm{ML}_{4}$ arrangement. Since some prearrangement occurs in solution before crystal growth ensues, $\mathrm{ML}_{4}$ could then also be present in solution (with similar interactions with $\mathrm{K}^{+}$in this work) especially at the high ligand-to-metal concentration ratios used here.

Burford(36-40) has used EIS-MS to identify various Bi(III)-ligand species in solution. Thus, in order to further investigate the existence of $\mathrm{ML}_{4}$ in solution, ESI-MS was also used here. The solution conditions were optimized to promote the formation of the species in question based on the calculated formation constants (in Table 2). Aqueous solutions with $1 \times 10^{-4} \mathrm{M} \mathrm{Bi}$ (III) were prepared with an excess of PA required to prevent precipitation $\left(\left[\mathrm{PA}_{\mathrm{T}}\right]:\left[\mathrm{Bi}_{\mathrm{T}}\right]=100\right)$. The excess PA was also needed to ensure $\mathrm{ML}_{4}$ was the dominant species in solution at $\mathrm{pH} 4.0$, if it did form (see the SDDs in Figure $\mathrm{S} 5$ in the Supporting Information). At pH 6.9, either $\mathrm{ML}_{3}(\mathrm{OH})$ or $\mathrm{ML}_{4}(\mathrm{OH})$ would be dominant. The mass-to-charge ratio $(\mathrm{m} / \mathrm{z})$ range in which data was collected was chosen such that large peaks due to the excess ligand were excluded as far as possible.

Table 3 gives the peak assignments for the detection of the positive and negative ions at (a) pH 4.0 and (b) pH 6.9 where only $\mathrm{m} / \mathrm{z}$ of the most abundant isotope is quoted (see Figures $\mathrm{S} 6$ and $\mathrm{S} 7$ for the spectra in the Supporting Information). At pH 4.0, the formation of $\mathrm{ML}_{4}$ was clearly seen as the anion $\mathrm{BiL}_{4}{ }^{-}$and the cation $\mathrm{K}_{2} \mathrm{BiL}_{4}{ }^{+}$, where the latter could be directly correlated to the structure in Figure $\mathrm{S} 4$ in the Supporting Information. $\mathrm{ML}_{3}$ is present as $\mathrm{KBiL}_{3}{ }^{+}$but is not observed in the spectra for negative ions due to $\mathrm{Bi}_{3}$ being neutral, and no further protons can be lost to produce an anion. At $\mathrm{pH}$ 6.9, a small peak at $m / z$ of 357 indicated the presence of $\mathrm{BiL}_{4}(\mathrm{OH})^{2-}$, but no peak was found at $\mathrm{m} / \mathrm{z}$ of 592 to denote $\mathrm{BiL}_{3}(\mathrm{OH})^{-}$at either solution $\mathrm{pH}$. These results clearly reinforce the species model including $\mathrm{ML}_{4}$ and $\mathrm{ML}_{4}(\mathrm{OH})$ rather than $\mathrm{ML}_{3}(\mathrm{OH})$. 
Table 3. Assignment of the Mass Spectra Peaks (Figures S6 and S7 in the Supporting Information) for Positive and Negative lons of Species Containing Bi(III) ${ }^{a}$

\section{(a) $\mathrm{pH} 4.0$}

$m / z$ (+ve) assignment (+ve) $m / z$ (-ve) assignment (-ve)

$\begin{array}{lccc}614 & \mathrm{KBiL}_{3}^{+} & 697 & \mathrm{BiL}_{4}^{-} \\ 775 & \mathrm{~K}_{2} \mathrm{BiL}_{4}^{+} & 858 & \mathrm{KBiL}_{5}^{-} \\ 936 & \mathrm{~K}_{3} \mathrm{BiL}_{5}^{+} & 1019 & \mathrm{~K}_{2} \mathrm{BiL}_{6}^{-} \\ 1097 & \mathrm{~K}_{4} \mathrm{BiL}_{6}^{+} & & \\ 876 & \mathrm{~K}_{3} \mathrm{BiL}_{4}\left(\mathrm{NO}_{3}\right)^{+} & \\ 977 & \mathrm{~K}_{4} \mathrm{BiL}_{4}\left(\mathrm{NO}_{3}\right)_{2}^{+} & & \\ 1037 & \mathrm{~K}_{4} \mathrm{BiL}_{5}\left(\mathrm{NO}_{3}\right)^{+} & & \end{array}$

(b) pH 6.9

$m / z$ (+ve) assignment (+ve) $m / z$ (-ve) assignment (-ve)

$\begin{array}{lllc}614 & \mathrm{KBiL}_{3}^{+} & 697 & \mathrm{BiL}_{4}^{-} \\ 775 & \mathrm{~K}_{2} \mathrm{BiL}_{4}^{+} & 357 & \mathrm{BiL}_{4}(\mathrm{OH})^{2-} \\ 936 & \mathrm{~K}_{3} \mathrm{BiL}_{5}^{+} & & \\ 1097 & \mathrm{~K}_{4} \mathrm{BiL}_{6}^{+} & & \end{array}$

${ }^{a}$ Solutions analyzed contained $1 \times 10^{-4} \mathrm{M} \mathrm{Bi}(\mathrm{III})$ and $1 \times 10^{-2} \mathrm{M} \mathrm{PA}$ in $0.5 \mathrm{M} \mathrm{NO}_{3}^{-}$adjusted to (a) pH 4.0 and (b) pH 6.9.

Species with the $\mathrm{ML}_{5}$ and $\mathrm{ML}_{6}$ stoichiometry were also detected at both pHs by ESI-MS.

Unfortunately, the relative abundance is not necessarily an indication of the concentration of the species, as it depends on various other influences such as the efficiency of ionization, the mechanism of detection, and factors leading to disproportionate transmission of the ions between the ionization source and the detector. It was thus attempted to include these species in the model when analyzing the voltammetric data, but their $\log \beta$ values could not be refined. If they were present in solution under the conditions for the polarographic experiments, they were certainly minor species. Also, direct correlation between the ESI-MS results and the solution species should be treated with caution as the temperature and concentration conditions (among others) experienced by the complexes change as evaporation of the solvent occurs before the ions are left in a gas phase and analyzed.(41)

When assigning the peaks of species not containing Bi(III) (see Table S2 in the Supporting Information), it was noted that the ligand underwent polymerization with the inclusion of $\mathrm{K}^{+}$ions to 
varying degrees, especially when analyzing solutions at $\mathrm{pH}$ 6.9. This is not surprising for ESI, as adducts could form with other solute or solvent species.(41) The more extensive polymerization of $\mathrm{PA}$ at $\mathrm{pH} 6.9$ could be due to the higher concentration of $\mathrm{K}^{+}$present and the almost complete deprotonation of the ligand at this $\mathrm{pH}$. The $\mathrm{K}^{+}$could act as a bridge between two PA ligands (as observed in Figure $\mathrm{S} 4$ in the Supporting Information), or it could also be coordinated to the PA through the pyridine nitrogen atom and a carboxylate oxygen atom. To achieve the $\mathrm{K}^{+}$-to- $\mathrm{L}^{-}$ratios observed, it is speculated that both processes occur to produce the cations, but possibly only bridging occurs in the anions.

\subsection{Determining Stability Constants When Incorporating the Bi(III)-Nitrates as Competing Species Using a Spreadsheet}

In order to circumvent the problem of having competing $\mathrm{Bi}(\mathrm{III})$-nitrate species in solution and the available software being unable to deal with this, it was decided to devise a simple spreadsheet to calculate the stability constants when incorporating the $\mathrm{Bi}(I I I)-$ nitrate species. This involved calculating MBEs for $[M],[L],[H]$, and $[X]$ (where $X$ represents nitrate) which contain both the known formation constants and those to be refined. A number of assumptions needed to be made up front for these calculations to be feasible, as was done by Foti et al.(42) (i) Since $\left[M_{T}\right]$ is very low $\left(\leq 1 \times 10^{-5}\right.$ $M)$, it was assumed that no polynuclear species are formed. (ii) Since $\left[\mathrm{L}_{\mathrm{T}}\right]:\left[\mathrm{M}_{\mathrm{T}}\right]>\sim 94$, it was assumed that $\left[L_{T}\right]$ is significantly greater than the concentration of all the metal-ligand species formed (i.e., $\left.\sum\left[\mathrm{ML}_{\mathrm{q}} \mathrm{H}_{\mathrm{r}}\right]\right)$, and thus, when calculating $[\mathrm{L}]$, only the extent of protonation of the ligand needs to be considered. (iii) Since the concentration of nitrate in solution is 50000 times more than that of $\mathrm{Bi}(\mathrm{III})$, it was assumed that $\left[\mathrm{X}_{\mathrm{T}}\right]$ is significantly greater than the concentration of all the $\mathrm{Bi}(\mathrm{III})$-nitrate species formed (i.e., $\Sigma\left[\mathrm{MX}_{z}\right]$ ). Also, nitrate was assumed to be fully deprotonated, thus $\left[\mathrm{X}_{\mathrm{T}}\right]=[\mathrm{X}]$. The simplified MBEs used for $[\mathrm{L}]$ and $[\mathrm{M}]$ were

$$
\begin{aligned}
& {[\mathrm{L}]=\left[\mathrm{L}_{\mathrm{T}}\right] /\left(1+\sum_{r} \beta_{01 r}[\mathrm{H}]^{r}\right)} \\
& {[\mathrm{M}]=\left[\mathrm{M}_{\mathrm{T}}\right] / 1+\left(\sum_{q} \sum_{\mathrm{r}} \beta_{1 \% \mathrm{r}}[\mathrm{L}]^{q}[\mathrm{H}]^{r}+\sum_{z} \beta_{1 z}^{r}[\mathrm{X}]^{z}\right)}
\end{aligned}
$$

where $\beta^{\prime}{ }_{1 z}$ (for $\left.z=1-4\right)$ refers to the formation constants for the Bi(III)-nitrate species. [H] (and $[\mathrm{OH}]$ ) were determined directly from the $\mathrm{pH}$ measurements. A more detailed discussion can be found in the Supporting Information.

Therefore, when analyzing the data using the spreadsheet, the ECFCs were calculated using the $E(\mathrm{Bi})$ value (as illustrated in Figure 1) throughout the $\mathrm{pH}$ range employed. When calculating the CCFCs, the $\mathrm{Bi}(\mathrm{III})$ nitrates were included in the species model and their $\log \beta$ values were fixed (as given in Table 1). The average $\log \beta$ values now refined for the Bi(III)-PA system (see Table 4) compared to those determined in Table 2 for this work, except for the $\log \beta(\mathrm{ML})$ value which was now $0.8 \log$ units greater. Note that only the species model including $\mathrm{ML}_{4}$ and $\mathrm{ML}_{4} \mathrm{OH}$ is considered here, as confirmed by independent techniques. The complex formation curves (CFCs) and the $\log \beta$ values for each experiment are shown in Figure S9a and Table S3a in the Supporting Information, respectively. 
Table 4. Comparison of Average $\log \beta$ Values at $25^{\circ} \mathrm{C}$ for the Proposed Species at lonic Strength $0.25-0.5 \mathrm{M}$ $(\mathrm{K}, \mathrm{H}) \mathrm{NO}_{3}$ Using Two Different Calculation Strategies

use spreadsheet with a fixed $E(B i)$ and include $M X_{z}$ species

ML $\quad 7.77 \pm 0.07$

$\mathrm{ML}_{2} \quad 13.89 \pm 0.07$

$\mathrm{ML}_{3} \quad 18.606 \pm 0.005$

$\mathrm{ML}_{4} \quad 22.7 \pm 0.2$

$\mathrm{ML}_{4} \mathrm{OH} 31.4 \pm 0.2$ use dedicated software with a sliding $E_{c}(B i)$
$7.50 \pm 0.12$

$13.98 \pm 0.06$

$18.51 \pm 0.04$

$22.8 \pm 0.2$

$31.4 \pm 0.2$

From the CFCs plotted in Figure 4 (in red), it was noted that in the very acidic region $(\mathrm{pH}<\sim 0.8$ ) the CCFC was greater than the ECFC $(\Delta)$. To assess the reason for this, a SDD was plotted for the actual titration conditions, i.e., using the concentrations determined from solving the MBEs at each step in the titration (Figure $5 \mathrm{a}$ ). It is clear that the $\mathrm{Bi}(\mathrm{III})$-nitrates are dominant at these low pHs, which is highlighted by summing the percentage of all of these species (indicated by $\sum M X_{z}$ ). The slight overestimation of the CCFC is thus probably due to the $\log \beta$ values for the $\mathrm{Bi}(\mathrm{III})$-nitrate species not being very accurate as they are small. It is only due to nitrate having a concentration 50000 times that of $\mathrm{Bi}(\mathrm{III})$, that these species are present at significant concentrations at low $\mathrm{pH}$.

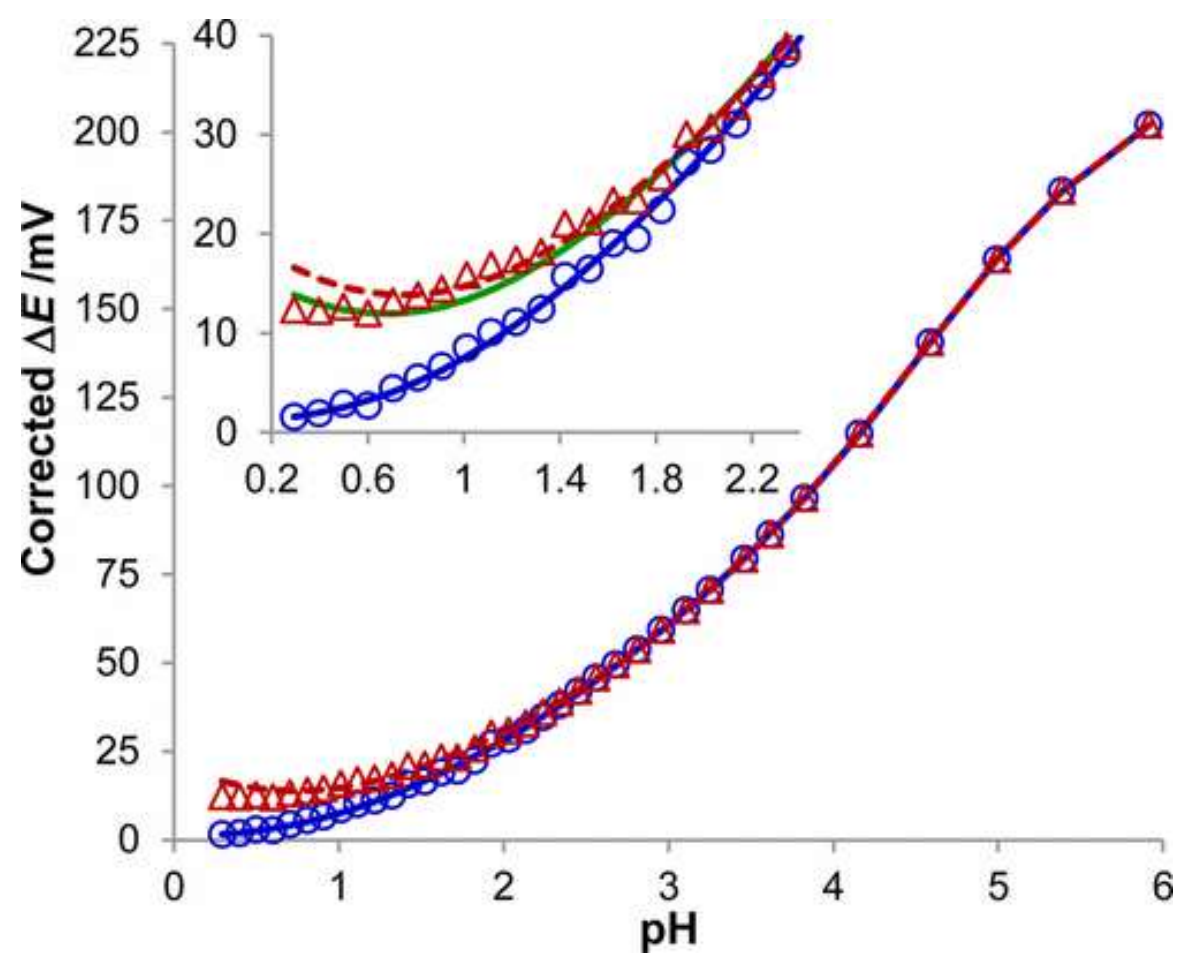

Figure 4. ECFCs for $\left[\mathrm{PA}_{T}\right]:\left[\mathrm{Bi}_{\mathrm{T}}\right]=94$ as determined using the spreadsheet $(\Delta)$ or the 3D-CFC software with a sliding $E_{\mathrm{c}}(\mathrm{M})(\mathrm{O})$ for the $\mathrm{ML}, \mathrm{ML}_{2}, \mathrm{ML}_{3}, \mathrm{ML}_{4}, \mathrm{ML}_{4} \mathrm{OH}$ species model. The CCFCs are given as dotted or solid lines, respectively. 

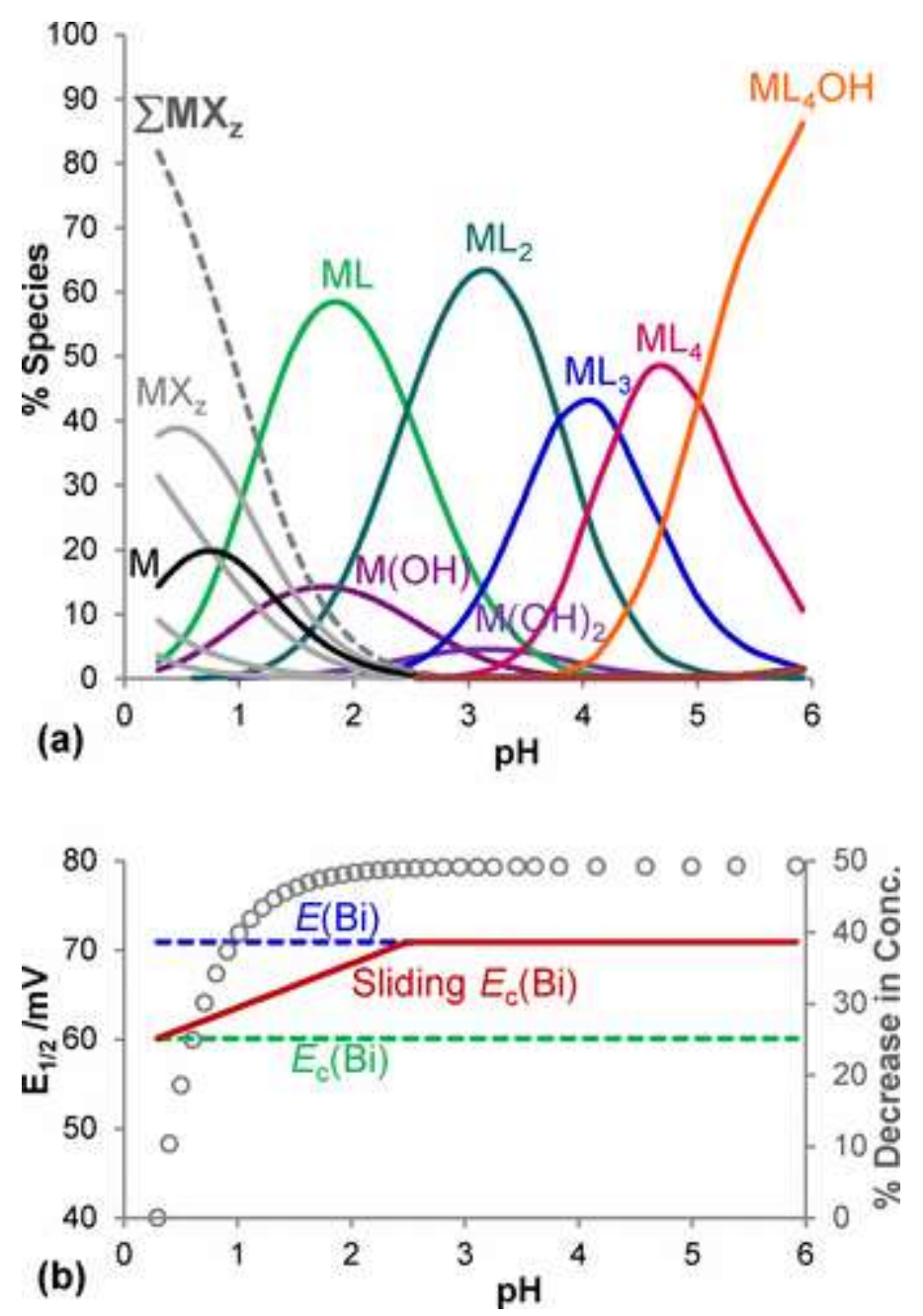

Figure 5. (a) The SDD for $\left[\mathrm{Bi}_{\mathrm{T}}\right]:\left[\mathrm{PA}_{\mathrm{T}}\right]=94$ where the changing concentrations as determined at each pH step were used. (b) The percentage decrease in concentration of $\mathrm{Bi}(\mathrm{III}), \mathrm{PA}$, and nitrate is shown together with the sliding $E_{\mathrm{c}}(\mathrm{Bi})$ values.

The fairly rapid decrease in concentration of the $\mathrm{Bi}(\mathrm{III})$-nitrates in Figure $5 \mathrm{a}$ was initially unexpected especially when compared to the SDDs in Figures 1 and 3, even though the changing total concentrations of $\mathrm{Bi}(\mathrm{III}), \mathrm{PA}$, and nitrate (see Figure $5 \mathrm{~b}$ ) were now being accounted for together with the changing $\mathrm{pH}$. These calculations were verified by employing data from SDDs plotted using the program Sol-eq.(43) A series of SDDs were plotted using the Bi(III), PA, and nitrate concentrations at each $\mathrm{pH}$ step in the titration and the $\log \beta$ values refined (Table 4). Only the data (i.e., the resultant percentage of each species) for the particular $\mathrm{pH}$ at which these concentrations applied were extracted. The data at each $\mathrm{pH}$ (and concentrations) were then combined, and the plot produced was the same as that in Figure 5a. Therefore, when refining data with PA and nitrate as competing ligands, it appears that the ML species forms to a greater extent from lower pHs than initially predicted. The green line in the inset of Figure 4 shows the CCFC when the formation constants determined in Table 2 were used together with that for the nitrate species. This clearly indicates the effect of using $E(\mathrm{Bi})$ throughout when incorporating nitrate as a competing ligand and why the log $\beta(\mathrm{ML})$ values refined were larger in this case. It was thus concluded that the calculations in section 3.1 where the fixed value of $E_{\mathrm{c}}(\mathrm{Bi})$ was used for data up to $\mathrm{pH} 1$ (based on the SDD plotted under fixed concentration conditions) gave erroneously low $\log \beta(\mathrm{ML})$ values. 
Simply for comparison, a sliding $E_{\mathrm{c}}(\mathrm{Bi})$ was used to calculate the ECFC from $\mathrm{pH} 0.3$ to the $\mathrm{pH}$ at which less than $1 \%$ of $\mathrm{Bi}(I I I)$ existed as nitrate species (the actual $\mathrm{pH}$ differed according to $\left[\mathrm{L}_{\mathrm{T}}\right]:\left[\mathrm{M}_{\mathrm{T}}\right]$ ). The value of $E_{\mathrm{c}}(\mathrm{Bi})$ at $\mathrm{pH} 0.3$ corresponded to the fixed value used as indicated in Figure 1, and once again, a linear variation between this value and $E(\mathrm{Bi})$ was determined, as shown in Figure $5 \mathrm{~b}$ (red line). The 3D-CFC software was utilized to recalculate the formation constants on the basis of the amended free $\mathrm{Bi}(\mathrm{III})$ potentials, and a CFC plot is shown in Figure 4 (in blue) (see Figure S9b in the Supporting Information for all of the CFC plots). The average $\log \beta$ values obtained when using the sliding $E_{\mathrm{c}}(\mathrm{Bi})$ are also given in Table 4 (see Table $\mathrm{S} 3$ in the Supporting Information for all of the results), and it was noted that $\log \beta(\mathrm{ML})$ was now $0.5 \log$ units greater than that in Table 2 . This highlights how assumptions about the $E_{\mathrm{c}}(\mathrm{Bi})$ values used could affect calculated $\log \beta$ values, emphasizing the importance of rather incorporating the nitrates in the species model and using $E(B i)$.

\subsection{Comparison to Previous Methodology}

Due to differences between the literature results and those obtained in this work, the approach used by Cukrowski et al.(30) was considered in more detail. They performed two consecutive pH titrations employing the same conditions, the one omitting the ligand and the other including the ligand. For the titration where the ligand was absent, the expected potential shift due to hydrolysis of $\mathrm{Bi}(\mathrm{III})$ was calculated and added to the experimental $E_{1 / 2}(\mathrm{Bi})$ values (acquired up to $\mathrm{pH} 2.1$ after which precipitation occurred). This new potential vs $\mathrm{pH}$ relationship was fitted using a third order polynomial which approached a constant value at $\mathrm{pH} \sim 2.5$. Thus, when analyzing data to calculate formation constants, below $\mathrm{pH} 2.5, \Delta E=E(\mathrm{Bi})-E\left(\mathrm{Bi}_{\text {comp }}\right)$ was calculated as the difference between this polynomial and the $E_{1 / 2}(\mathrm{Bi})$ values obtained from the titration including the ligand. Above $\mathrm{pH} 2.5$, $E(B i)$ was set equal to the constant value.

There are several possible sources of error in their approach. (i) The GE was calibrated by $0.5 \mathrm{M}$ $\mathrm{HNO}_{3}-0.5 \mathrm{M} \mathrm{NaOH}$ titration, and a straight line relationship was assumed across the $\mathrm{pH}$ range. This was shown not to be the case,(22) but due to the outstanding performance of the $\mathrm{GE}$, this calibration should only introduce small errors at the lowest $\mathrm{pHs}$. (ii) Having separate $\mathrm{pH}$ titrations (one without and one with the ligand in solution) could lead to small errors, as it is our experience that slight fluctuations in the reference system could occur between each multihour titration experiment. In this work, $\Delta E=1.7 \mathrm{mV}$ (for $\left[\mathrm{PA}_{\mathrm{T}}\right]:\left[\mathrm{Bi}_{\mathrm{T}}\right]=197$ and $\left[\mathrm{Bi}_{\mathrm{T}}\right]=1 \times 10^{-5} \mathrm{M}$ ) at $\mathrm{pH} 0.3$ when the polarograms were collected directly after each other (see Figure $\mathrm{S} 1$ in the Supporting Information), whereas Cukrowski et al. (30) found $\Delta E \sim 5 \mathrm{mV}$ (for $\left[\mathrm{PA}_{\mathrm{T}}\right]:\left[\mathrm{Bi}_{\mathrm{T}}\right]=132$ and $\left[\mathrm{Bi}_{\mathrm{T}}\right]=5 \times 10^{-5} \mathrm{M}$ ) at approximately the same $\mathrm{pH}$ for consecutive experiments. When calculating the expected shift at $\mathrm{pH}$ 0.3 for the formation of $\mathrm{ML}$ (using the same PA and $\mathrm{Bi}(\mathrm{III})$ concentrations they used), it was found to be $4.2 \mathrm{mV}$ when $\log \beta(\mathrm{ML})=7.5$ and $1.7 \mathrm{mV}$ when $\log \beta(\mathrm{ML})=7.0$. Introducing $\mathrm{TI}(\mathrm{I})$ as an internal reference minimizes this error as far as possible. (iii) $\mathrm{Bi}(\mathrm{OH})_{2}{ }^{+}$was not included as one of the hydrolysis products, and since this species exists below pH 2.1 (see Figure 1), it would affect the values fitted by the polynomial. Again this would only have a small effect, as the $\mathrm{Bi}(\mathrm{OH})_{2}{ }^{+}$ concentrations are small (about $12 \%$ of the $\mathrm{Bi}(\mathrm{III})$ exists as $\mathrm{Bi}(\mathrm{OH})_{2}{ }^{+}$at $\mathrm{pH} 2$ in a $0.5 \mathrm{M}$ nitrate solution). (iv) By using the third order polynomial values as the $E(B i)$ values, the shifts in potential due to the formation of the $\mathrm{Bi}(\mathrm{III})$-nitrates were inadvertently accounted for to an extent; however, the authors mistakenly incorporated these potential shifts as part of the changing $E_{\mathrm{j}}$. That being said, neglecting to account for the $\mathrm{Bi}(\mathrm{III})$-nitrates resulted in the fraction of $\mathrm{Bi}(\mathrm{III})$-hydroxides present in 
solution being overestimated especially in the low $\mathrm{pH}$ range and consequently in larger shifts in potential due to the formation of $\mathrm{Bi}(\mathrm{III})$-hydroxides being predicted. The values thus used to fit the polynomial were inaccurate. This issue was evident from their results for the ligand titrations. These were performed at $\mathrm{pH} 0.9,1.37$, and 1.85 , and the respective $\log \beta(\mathrm{ML})$ values obtained were 7.50 , 7.66, and 7.89.(30) They speculated that the systematic error observed was due to the formation constant for $\mathrm{BiOH}^{2+}$ being too high, but it is actually due to the omission of competing nitrates which effectively reduces the concentration of $\mathrm{Bi}(\mathrm{III})$-hydroxides in solution as the $\mathrm{pH}$ decreases. Interestingly, these results are comparable to the $\log \beta(\mathrm{ML})$ value of $7.77 \pm 0.07$, obtained from calculations using the spreadsheet. It is suspected that the ligand results obtained the higher $\mathrm{pHs}$ would be more accurate because the concentrations of $\mathrm{Bi}(\mathrm{III})$-nitrate species are lower and hence would affect the calculation of the $E(\mathrm{Bi})$ value they used to less of an extent. It should be mentioned that one of the limitations used in this work is relying on the $\log \beta$ values for the $\mathrm{Bi}(I I I)$-nitrate species which are small and difficult to determine accurately.

For interest, the $\log \beta$ values for the $\mathrm{Bi}(\mathrm{III})$-picolinic acid species were compared to that for the picolinates of other metal ions, including some of biomedical interest. The results presented in Table S4 in the Supporting Information clearly show the high stability of these $\mathrm{Bi}(\mathrm{III})$ complexes, with values comparable to that for the $\mathrm{Cu}(\mathrm{II})$ and $\mathrm{Hg}(\mathrm{II})$ complexes (both of which only form the ML and $\mathrm{ML}_{2}$ species). Only La(III), as well as the other lanthanide ions, also formed $\mathrm{ML}_{4}$ species.(33)

\section{Conclusion}

Methodologies developed to study $\mathrm{Bi}(\mathrm{III})$ complex formation using voltammetry were successfully applied in this work. The importance of including nitrate as a competing ligand when determining formation constants for $\mathrm{Bi}(\mathrm{III})$-ligand species in a nitrate background was highlighted. This was not achievable using the dedicated software available; thus, a spreadsheet was designed to do these calculations. The spreadsheet also enabled the plotting SDDs for the actual titration conditions (rather than at fixed concentrations as is usually the case), which more clearly revealed the changes occurring in solution during the experiment. The use of crystal structures and ESI-MS data allowed for the corroboration of the species model chosen.

\section{Supporting Information}

(1) A list describing selected symbols, (2) information from polarographic-pH titrations, (3) a structure of a $\mathrm{Bi}(\mathrm{III})-\mathrm{PA}$ complex, (4) information regarding ESI-MS studies, (5) the derivation of the MBEs used to calculate formation constants using a spreadsheet, (6) information from polarographic-pH titrations when nitrates are included as competing species, (7) comparison of stability constants for various metal ion-picolinic acid complexes (PDF) 


\section{Author Contributions}

The manuscript was written through contributions of all authors. All authors have given approval to the final version of the manuscript.

The authors declare no competing financial interest.

\section{Acknowledgment}

The authors thank Marelise Ferreira for her assistance with the ESI-MS measurements. This work is based on the research supported by the National Research Foundation (NRF) of South Africa and the University of the Witwatersrand. Any opinion, finding and conclusion or recommendation expressed in this material is that of the authors and the NRF does not accept responsibility in this regard.

\section{References}

1. Berners-Price, S. J.; Sadler, P. J.Coordination Chemistry of Metallodrugs: Insights into Biological Speciation from NMR Spectroscopy Coord. Chem. Rev. 1996, 151, 1-40, DOI: 10.1016/S0010-8545(96)90191-5

2. Briand, G.; Burford, N.Bismuth Compounds and Preparations with Biological or Medicinal Relevance Chem. Rev. 1999, 99, 2601-2657, DOI: 10.1021/cr980425s

3. Sadler, P. J.; Li, H.; Sun, H.Coordination Chemistry of Metals in Medicine: Target Sites for Bismuth Coord. Chem. Rev. 1999, 185-186, 689- 709, DOI: 10.1016/S0010-8545(99)00018-1

4. Hassfjell, S.; Brechbiel, M. W.The Development of the $\alpha$-Particle Emitting Radionuclides 212 $\mathrm{Bi}$ and $213 \mathrm{Bi}$, and their Decay Chain Related Radionuclides for Therapeutic Applications Chem. Rev. 2001, 101, 2019- 2036, DOI: 10.1021/cr000118y

5. Tiekink, E. R. T.Antimony and Bismuth Compounds in Oncology Crit. Rev. Oncol. Hematol. 2002, 42, 217- 224, DOI: 10.1016/S1040-8428(01)00217-7

6. Yang, N.; Sun, H.Biocoordination Chemistry of Bismuth: Recent Advances Coord. Chem. Rev. 2007, 251, 2354-2366, DOI: 10.1016/j.ccr.2007.03.003

7. Yang, Y.; Ouyang, R.; Xu, L.; Guo, N.; Li, W.; Feng, K.; Ouyang, L.; Yang, Z.; Zhou, S.; Miao, Y.Review: Bismuth Complexes: Synthesis and Applications in Biomedicine J. Coord. Chem. 2015, 68, 379-397, DOI: 10.1080/00958972.2014.999672

8. Abrams, M. J.; Murrer, B. A.Metal Compounds in Therapy and Diagnosis Science 1993, 261, 725- 730, DOI: 10.1126/science.8102010

9. Dittes, U.; Vogel, E.; Keppler, B. K.Overview on Bismuth(III) and Bismuth(V) Complexes with Activity Against Helicobacter Pylori Coord. Chem. Rev. 1997, 163, 345- 364, DOI: 10.1016/S0010-8545(97)00042-8

10. Lambert, J. R.; Midolo, P.The Actions of Bismuth in the Treatment of Helicobacter Pylori Infection Aliment. Pharmacol. Ther. 1997, 11, 27-33, DOI: 10.1046/j.1365-2036.11.s1.13.x

11. Zhang, L.; Mulrooney, S. B.; Leung, A. F. K.; Zeng, Y.; Ko, B. B. C.; Hausinger, R. P.; Sun, H.Inhibition of Urease by Bismuth(III): Implications for the Mechanism of Action of Bismuth Drugs BioMetals 2006, 19, 503- 511, DOI: 10.1007/s10534-005-5449-0 
12. Nakhla, V.; Takwonoingi, Y. M.; Sinha, A.Myringoplasty: A Comparison of Bismuth lodoform Paraffin Paste Gauze Pack and Tri-Adcortyl Ointment Ear Dressing J. Laryngol. Otol. 2007, 121, 329- 332, DOI: 10.1017/S0022215106002660

13. Brorson, $\varnothing$.; Brorson, S.-H.Susceptibility of Motile and Cystic Forms of Borrelia Burgdorferi to Ranitidine Bismuth Citrate Int. Microbiol. 2001, 4, 209- 215, DOI: 10.1007/s10123-001-00397

14. Murafuji, T.; Miyoshi, Y.; Ishibashi, M.; Rahman, A. F. M. M.; Sugihara, Y.; Miyakawa, I.; Uno, H.Antifungal Activity of Organobismuth Compounds Against the Yeast Saccharomyces Cerevisiae: Structure-Activity Relationship J. Inorg. Biochem. 2004, 98, 547-552, DOI:

15. Wang, X.; Zhang, X.; Lin, J.; Chen, J.; Xu, Q.; Guo, Z.DNA-Binding Property and Antitumor Activity of Bismuth(III) Complex with 1,4,7,10-Tetrakis(2-Pyridylmethyl)-1,4,7,10Tetraazacyclododecane J. Chem. Soc., Dalton Trans. 2003, 2379-2380, DOI: 10.1039/b305290g

16. Song, Y. J.; Qu, C. F.; Rizvi, S. M. A.; Li, Y.; Robertson, G.; Raja, C.; Morgenstern, A.; Apostolidis, C.; Perkins, A. C.; Allen, B. J.Cytotoxicity of PAI2, C595 and Herceptin Vectors Labeled with the Alpha-Emitting Radioisotope Bismuth-213 for Ovarian Cancer Cell Monolayers and Clusters Cancer Lett. 2006, 234, 176- 183, DOI: 10.1016/j.canlet.2005.03.060

17. Baes, C. F., Jr.; Mesmer, R. E. The Hydrolysis of Cations; John Wiley and Sons Inc.: New York, 1976.

18. Kragten, J.; Decnop-Weever, L. G.; Gründler, P.Mixed Hydroxide Complex Formation and Solubility of Bismuth in Nitrate and Perchlorate Medium Talanta 1993, 40, 485-490, DOI: 10.1016/0039-9140(93)80004-B

19. Nancollas, G. H.; Tomson, M. B.Guidelines for the Determination of Stability Constants Pure Appl. Chem. 1982, 54, 2675- 2692, DOI: 10.1351/pac198254122675

20. Brandariz, I.; Barriada, J. L.; Vilariño, T.; Sastre de Vicente, M. E.Comparison of Several Calibration Procedures for Glass Electrodes in Proton Concentration Monatsh. Chem. 2004, 135, 1475-1488, DOI: 10.1007/s00706-004-0239-x

21. Hitchcock, D. I.; Taylor, A. E.The Standardization of Hydrogen Ion Determinations. I. Hydrogen Electrode Measurements with a Liquid Junction J. Am. Chem. Soc. 1937, 59, 1812 1818, DOI: $10.1021 / \mathrm{ja01289a007}$

22. Billing, C.; Cukrowski, I.Glass Electrode Calibration for Use in the Voltammetric Determination of Stability Constants under Extreme Acidic Conditions S. Afr. J. Chem. 2009, 62,168

23. Billing, C.; Cukrowski, I.; Jordan, B.A Novel Approach to Monitoring of the Diffusion Junction Potential in Speciation Studies by Polarography under Very Acidic Conditions. Part I: The Reversible Cd(II)-Picolinic Acid System Electroanalysis 2013, 25, 2221- 2230, DOI: 10.1002/elan.201300256

24. Billing, C.; Cukrowski, I.A Novel Approach to Monitoring of the Diffusion Junction Potential in Speciation Studies by Polarography under Very Acidic Conditions. Part II: The QuasiReversible Cu(II)-Picolinic Acid System Electroanalysis 2015, 27, 494- 502, DOI: 10.1002/elan.201400466

25. Billing, C.; Cukrowski, I.Measurements and Modelling to Determine the Reduction Potential of Uncomplexed $\mathrm{Bi}(\mathrm{III})$ in Nitrate Solutions for Application in $\mathrm{Bi}(\mathrm{III})$-ligand Equilibria Studies by Voltammetry J. Phys. Chem. B 2016, 120, 468-478, DOI: 10.1021/acs.jpcb.6b00670

26. Grant, R. S.; Coggan, S. E.; Smythe, G. A.The Physiological Action of Picolinic Acid in the Human Brain Int. J. Tryptophan Res. 2009, 2, 71- 79

27. Krieger, I.; Cash, R.; Evans, G. W.Picolinic Acid in Acrodermatitis Enteropathica: Evidence for a Disorder of Tryptophan Metabolism J. Pediatr. Gastroenterol. Nutr. 1984, 3, 62-68, DOI: 10.1097/00005176-198401000-00014 
28. Aggett, P. J.; Fenwick, P. K.; Kirk, H.An In Vitro Study of the Effect of Picolinic Acid on Metal Translocation across Lipid Bilayers J. Nutr. 1989, 119, 1432- 1437

29. Evans, G. W.; Johnson, P. E.Characterization and Quantitation of a Zinc-Binding Ligand in Human Milk Pediatr. Res. 1980, 14, 876-880, DOI: 10.1203/00006450-198007000-00007

30. Cukrowski, I.; Zhang, J. M.; van Aswegen, A.Voltammetry as a Virtual Potentiometric Sensor in Modelling of a Metal/Ligand System and Refinement of Stability Constants. Part 2. Differential-Pulse- and Sampled-Current-Polarographic and Virtual Free-Metal-Ion Potentiometric Study of a Bismuth(III)/Picolinic Acid/Hydroxide System Helv. Chim. Acta 2004, 87, 2135- 2158, DOI: 10.1002/hlca.200490194

31. Cukrowski, I.; Mkwizu, T.; Magampa, P.Voltammetry as Virtual Potentiometric Sensor in Modelling of a Metal/Ligand System and Refinement of Stability Constants. Part 5. Complexation Studies of Hydrolysis-Prone Lead(II) with Glycine and Sarcosine by SampledDirect-Current Polarography Involving Virtual Potential Helv. Chim. Acta 2006, 89, 29342952, DOI: $10.1002 /$ hlca.200690263

32. Cukrowski, I.A polarographic method of speciation for labile metal-ligand systems based on mass-balance equations. A Differential Pulse Polarographic Study at Fixed Ligand to Metal Ratio and Varied pH Anal. Chim. Acta 1996, 336, 23- 36, DOI: 10.1016/S00032670(96)00335-2

33. Martell, A. E.; Smith, R. M.; Motekaitis, R. J. NIST Standard Reference Database 46 Version 8.0. NIST Critically Selected Stability Constants of Metal Complexes Database, Gaithersburg, MD, 2004.

34. Cukrowski, I.; Hancock, R. D.; Luckay, R. C.Formation Constant Calculation for Non-Labile Complexes Based on a Labile Part of the Metal-Ligand System. A Differential Pulse Polarographic Study at Fixed Ligand to Metal Ratio and Varied pH: Application to Polarographically Inactive Complexes Anal. Chim. Acta 1996, 319, 39-48, DOI: 10.1016/0003-2670(95)00467-X

35. Allen, F. H. The Cambridge Structural Database: A Quarter of a Million Crystal Structures and Rising, Acta Crystallogr., Sect. B, 2002, 58, 380-388. Cambridge Structural database Version 5.34, November 2012, update.

36. Burford, N.; Eelman, M. D.; Cameron, T. S.Comprehensive Characterisation of Bismuth Thiosalicylate Complexes: Models for Bismuth Subsalicylate Chem. Commun. 2002, 14021403, DOI: 10.1039/b203110h

37. Briand, G. G.; Burford, N.; Eelman, M. D.; Aumeerally, N.; Chen, L.; Cameron, T. S.; Robertson, K. N.Identification, Isolation, and Characterization of Cysteinate and Thiolactate Complexes of Bismuth Inorg. Chem. 2004, 43, 6495- 6500, DOI: 10.1021/ic049594n

38. Burford, N.; Eelman, M. D.; Groom, K.Identification of Complexes Containing Glutathione with $\mathrm{As}(\mathrm{III}), \mathrm{Sb}(\mathrm{III}), \mathrm{Cd}(\mathrm{II}), \mathrm{Hg}(\mathrm{II}), \mathrm{TI}(\mathrm{I}), \mathrm{Pb}(\mathrm{II})$ or $\mathrm{Bi}(\mathrm{III})$ by Electrospray Ionization Mass Spectrometry J. Inorg. Biochem. 2005, 99, 1992- 1997, DOI: 10.1016/j.jinorgbio.2005.06.019

39. Phillips, H. A.; Eelman, M. D.; Burford, N.Cooperative Influence of Thiolate Ligands on the Bio-Relevant Coordination Chemistry of Bismuth J. Inorg. Biochem. 2007, 101, 736- 739, DOI: 10.1016/j.jinorgbio.2007.01.003

40. Phillips, H. A.; Burford, N.Identification of Bismuth-Thiolate-Carboxylate Clusters by Electrospray Ionization Mass Spectrometry Inorg. Chem. 2008, 47, 2428- 2441, DOI: 10.1021/ic701657r

41. Fenn, J. B.; Mann, M.; Meng, C. K.; Wong, S. F.; Whitehouse, C. M.Electrospray IonizationPrinciples and Practice Mass Spectrom. Rev. 1990, 9, 37- 70, DOI: 10.1002/mas.1280090103

42. Foti, C.; Lando, G.; Millero, F. J.; Samartano, S.Experimental Study and Modelling of Inorganic $\mathrm{Cd}^{2+}$ Speciation in Natural Waters Environ. Chem. 2011, 8, 320- 331, DOI: 10.1071/EN10138

43. Petit, L. D.; Powell, K. J. Sol-Eq, version 2.2; Academic Software: 1998 